„Analecta Cracoviensia” 50 (2018), s. 79-99

DoI: http://dx.doi.org/10.15633/acr.3284

ks. Marek Kluz

Uniwersytet Papieski Jana Pawła II w Krakowie

\title{
Chrystocentryzm wiary w Lumen fidei papieża Franciszka
}

Wiara chrześcijańska opiera się na podwójnym doświadczeniu - doświadczeniu Jezusa Chrystusa obecnego w historii i doświadczeniu Jego obecności w sercu człowieka. Niestety, jak zauważa ojciec święty Franciszek w encyklice Lumen fidei - „nasza kultura straciła zdolność dostrzegania konkretnej obecności Boga, Jego działania w świecie. Uważamy, że Bóg znajduje się w zaświatach, na innym poziomie rzeczywistości, oddzielony od naszych konkretnych relacji. Gdyby jednak tak było, gdyby Bóg nie był zdolnym do działania w świecie, Jego miłość nie byłaby prawdziwie potężna, prawdziwie rzeczywista, a zatem nie byłaby nawet prawdziwą miłością, zdolną zapewnić to szczęście, które obiecuje. Wówczas byłoby całkowicie obojętne, czy się w Niego wierzy, czy nie wierzy. Natomiast chrześcijanie wyznają konkretną i potężną miłość Boga, który naprawdę działa w historii i decyduje o jej ostatecznym przeznaczeniu. Tę miłość można spotkać, ona objawiła się w pełni w męce, śmierci i zmartwychwstaniu Chrystusa"'. Każdy zatem chrześcijanin jest wezwany do poznawania Jezusa Chrystusa w historii i w ludzkich sercach, by z tego poznania rodziło się i rozwijało doznanie, które będzie oparciem i umocnieniem wiary na drogach życia. Jako chrześcijanie wierzymy, że tylko Chrystus, który jest Objawicielem, wyjaśnia, kim jest człowiek, jaki jest sens jego życia oraz udziela odpowiedzi na stawiane przez niego pytania.

Poznać Jezusa Chrystusa oznacza więc wyciągnąć konsekwencje z tego poznania - konsekwencje bezpośrednio odnoszące się do wiary i życia człowieka.

\footnotetext{
1 Franciszek, Encyklika Lumen fidei [dalej: LF], Częstochowa 2013, nr 17.
} 
Wobec Chrystusa nie można pozostać obojętnym, albowiem - jak twierdzi papież Franciszek - tylko On jest zdolny „oświetlić całe życie człowieka”2. Dlatego celem niniejszego studium jest - w oparciu o encyklikę Lumen fidei Franciszka - uświadomienie potrzeby wskazania konsekwencji, które wywołują w człowieku postać Chrystusa i Jego dzieło. Chodzi więc o odniesienie prowadzonej refleksji chrystologicznej do naszego życia i o próbę znalezienia odpowiedzi na pytanie, kim jest Jezus Chrystus dla naszej wiary i kultury.

\section{Wiara w kontekście Objawienia}

Podstawą wiary chrześcijańskiej jest Pismo Świete, albowiem jest ono wyrazem Objawienia. Wiara zaś - jak to można wyrazić na wstępie - jest fundamentalną odpowiedzią na objawienie się Boga ${ }^{3}$. Ojciec święty Franciszek w encyklice Lumen fidei stwierdza, że „wiara stanowi odpowiedź na Słowo skierowane do osoby, daną pewnemu «Ty», które woła nas po imieniu”". A na innym miejscu tejże encykliki pisze: „Wiara jest bezinteresownym darem Boga, który wymaga pokory i odwagi, by zaufać i zawierzyć się, i w ten sposób dostrzec świetlaną drogę spotkania między Bogiem i ludźmi, historię zbawienia"s.

Chcąc jednak dobrze zrozumieć, czym jest wiara, należy - zdaniem Franciszka - „opowiedzieć jej historię [...], o której w pierwszym rzędzie świadczy Stary Testament" ${ }^{\prime \prime}$. Cała starotestamentalna wizja wiary sprowadza się do zawierzenia (ufności) Bogu i Jego obietnicom oraz posłuszeństwa Jego przykazaniom ${ }^{7}$. Ojciec święty we wspomanianej encyklice wyraźnie to podkreśla: „Wiara jawi się jako droga, jako szlak, który trzeba przemierzyć, a który zaczyna się od spotkania z Bogiem żywym. Dlatego w świetle wiary, całkowitego zawierzenia Bogu, który zbawia, Dekalog zyskuje swoją najgłębszą prawdę, która zawarta jest w słowach wprowadzających dziesięcioro przykazań: «Ja jestem Pan, Bóg twój, który cię wyprowadził z ziemi egipskiej» (Wj 20, 2)”8. Zawierzenie Bogu i powierzenie Mu siebie zakłada znajomość Jego zbawczego

\footnotetext{
LF 4 .

3 Por. Sobór Watykański II, Konstytucja dogmatyczna o Objawieniu Bożym Dei Verbum, nr 5, w: Sobór Watykański II, Konstytucje, dekrety, deklaracje, Poznań 2012.

$4 \quad$ LF 8.

5 LF 14.

${ }^{6}$ LF 8.

7 Por. S. Zawada, Wiara, w: Jan Paweł II, Encyklopedia nauczania moralnego, red. J. Nagórny, K. Jeżyna, Radom 2005, s. 568.

${ }^{8}$ LF 46.
} 
działania dla narodu wybranego, Jego dzieła Przymierza i samego Boga jako jedynego Zbawcy. To są fundamentalne powody, dla których Izrael powinien wierzyć w Boga?

Szczególnie ważne jest odczytanie wiary w kontekście idei Przymierza, jakie Bóg zawiera z całym ludem na Synaju za pośrednictwem Mojżesza ${ }^{10}$. Przymierze wyraża ideę stałej więzi Boga z człowiekiem i człowieka z Bogiem. Inicjatywa należy tu zawsze do Boga. To Bóg jest tym, który ustanawia Przymierze. Natomiast człowiek włącza się w to Przymierze poprzez dobrowolną decyzję. Ten właśnie akt przyjęcia daru Przymierza jest aktem wiary. I tak jak Bóg pozostaje wierny swemu Przymierzu, tak człowiek powinien objawić swoją wierność Bogu ${ }^{11}$. Kontekst Przymierza podkreśla, że w spotkaniu Boga z człowiekiem, które weryfikuje się przez wiarę, inicjatywa należy całkowicie do Boga ${ }^{12}$.

„Wszystkie wątki Starego Testamentu - jak zauważa papież Franciszek w Lumen fidei - zbiegają się w Chrystusie. On staje się ostatecznym «tak» dla wszystkich obietnic, fundamentem naszego ostatecznego «Amen», powiedzianego Bogu (por. 2 Kor 1, 20)”'13. Teocentryzm wiary w Starym Testamencie przybiera więc w Nowym Testamencie charakter chrystocentryczny ${ }^{14}$, oznacza to, że trzeba wierzyć Chrystusowi i w Chrystusa. Do tego czasu Bóg przemawiał słowami do swojego ludu za pośrednictwem proroków, jednak „w tych ostatecznych dniach przemówił do nas przez Syna” (Hbr 1, 1n). Zasadniczą perspektywę dla pojęcia wiary w Nowym Testamecie wyznacza więc prawda o Chrystusie, który jest „pełnym objawieniem wiarygodności Boga” ${ }^{15}$. Katechizm Kościoła Katolickiego poucza, że „dla chrześcijanina wiara w Boga jest nieodłczna od wiary w Tego, którego On posłał, «Jego umiłowanego Syna», w którym całkowicie sobie upodobał; Bóg polecił nam, aby Go słuchać. Sam Pan mówi do swoich uczniów: «Wierzycie w Boga? I we mnie wierzcie!» (J 14,1). Możemy wierzyć

9 Por. A. F. Dziuba, Dynamika wiary, Częstochowa 1997, s. 23-24.

${ }_{10}$ Por. LF 14; M. Łanoszka, Na drogach wiary biblijnego Izraela, w: Wierzę, red. P. Łabuda, Tarnów 2015, s. 24-33.

${ }^{11}$ Por. J. Nagórny, Fundamentalne zobowiązania moralne Izraela $w$ ramach etyki Przymierza, „Roczniki Teologiczno-Kanoniczne” 27 (1980) z. 3, s. 9-10.

${ }_{12}$ Por. R. Głuchowski, Zmaganie o czystość wiary w Jahwe, w: Wierzę..., dz. cyt., s. 58-59.

13 LF 15.

${ }^{14}$ Por. Sobór Watykański II, Konstytucja duszpasterska o Kościele w świecie współczesnym Gaudium et spes, nr 2, w: Sobór Watykański II, Konstytucje..., dz. cyt.; także: Sobór Watykański II, Konstytucja o liturgii świętej Sacrosanctum concilium, nr 5, w: Sobór Watykański II, Konstytucje..., dz. cyt.

${ }^{15}$ LF 15. 
w Jezusa Chrystusa, ponieważ On jest samym Bogiem, Słowem, które stało się ciałem: «Boga nikt nigdy nie widział, Ten Jednorodzony Bóg, który jest w łonie Ojca, o Nim pouczył» $(J$ 1, 18). Ponieważ On «widział Ojca» $(J 6,46)$, On sam Go zna i może Go objawić"'

Zgłębiając poszczególne pisma nowotestamentalne, daje się w nich zauważyć pewną specyfikę ujmowania istoty wiary. Nie ma w Nowym Testamencie jednego pojęcia wiary. Ewangelie synoptyczne ukazują przede wszystkim wezwanie Jezusa do wiary i konsekwencje tej wiary w życiu ludzkim. To wezwanie Jezusa do wiary jest wyraźnie włączone w orędzie o królestwie Bożym (Mk 1, 15) ${ }^{17}$. Jezus poświadcza swoje królestwo słowami i cudami. Te zaś zakładają wiarę w moc Bożą, która się objawiła w Jezusie (Mk 2, 5; 5, 34; 9, 14-29), ale przede wszystkim przygotowują drogę prawdziwej wierze, która idzie dalej niż rozpoznanie mocy Bożej i jest przyjęciem samej Osoby Chrystusa.

Wiara opisywana w ewangeliach synoptycznych jawi się jako całkowite oddanie się Bogu, całkowite zawierzenie $\mathrm{Mu}$ we wszelkich okolicznościach życia. Jest ona postawą wszechstronnej akceptacji królestwa Bożego, a w konsekwencji postawą całościowego przyjęcia Chrystusa. Jej wyrazem jest całkowite pójście za Jezusem i przyznanie się do Niego we wszelkich okolicznościach życia (Mt 10, 32) ${ }^{18}$.

Przyjmując Chrystusa, człowiek otrzymuje dar, światło, które nie tylko odsłania Boga, lecz także wewnętrznie z Nim łączy. Wskazuje na to cała Pawłowa teologia wiary, którą wykłada on w swoich listach oraz pismach mu przypisywanych. „Wychodząc od uczestnictwa w sposobie patrzenia Jezusa - podkreśla Franciszek w Lumen fidei - apostoł Paweł w swoich pismach dał nam opis życia człowieka wierzącego"' ${ }^{\text {"19 }}$. Dla św. Pawła wiara bowiem oznacza, że chrześcijanin oddaje się Chrystusowi i wchodzi naprawdę w tajemnicę Chrystusa. Wierzący powinien być i żyć „w Chrystusie”, a jego zawierzenie wyraża się w całkowitym posłuszeństwie, a ostatecznie prowadzi do miłości: „Albowiem w Chrystusie... [ma znaczenie] tylko wiara, która działa przez miłość” (Ga 5, 6). Z wiary też płynie zaufanie: „W Nim mamy śmiały przystęp do Ojca z ufnością, dzięki wierze w Niego" (Ef 3,12) ${ }^{20}$.

\footnotetext{
${ }^{16}$ Katechizm Kościoła Katolickiego, Pallottinum 1994, nr 151.

${ }_{17}$ Por. A. F. Dziuba, Dynamika wiary..., dz. cyt., s. 41.

18 Por. szerzej: M. Bednarz, Wiara w przekazie Ewangelii, w: Wierze..., dz. cyt., s. 71-118.

19 LF 19.

${ }^{20}$ Por. Benedykt xvi, List apostolski Porta fidei, Kraków 2012, nr 6. Por także: P. Łabuda, Wiara
} w nauce Apostoła Pawła, w: Wierzę..., dz. cyt., s. 135. 
Pawłowa koncepcja wiary, która powstaje w czasie popaschalnym, w niepodważalny sposób w centrum wiary stawia Chrystusa Zmartwychwstałego: „Jeżeli więc ustami wyznasz, że Jezus jest Panem, i w sercu swoim uwierzysz, że Bóg Go wskrzesił z martwych - osiągniesz zbawienie” (Rz 10, 9; por. 1 Kor 15, 3-28). Wiara w zmartwychwstanie Jezusa jest wiarą także w to, „że z Nim również żyć będziemy" (Rz 6, 8). Według papieża Franciszka cała doktrynalna postawa orędzia chrześcijańskiego, stanowiąca przedmiot aktu i spełnienia wiary, sprowadza się do zbawczego misterium Chrystusa. Jest to misterium wyciskające niezatarty ślad w życiu moralnym człowieka ${ }^{21}$.

Zmartwychwstanie Chrystusa jest podstawowym argumentem wiary Nowego Przymierza. Nieprzyjęcie tego faktu, który stanowi główny element apostolskiego przepowiadania, podważa prawdziwość głoszonej nauki i z głosicieli Ewangelii może uczynić „fałszerzy słowa Bożego”. Bez przyjęcia tego faktu, jak to podkreśla apostoł z Tarsu, „próżna jest nasza wiara” (1 Kor 15, 14). Bóstwo Chrystusa - Mesjasza ujawnia się w pełni przez śmierć, zmartwychwstanie i wniebowstąpienie. Obowiązkiem apostołów, świadków tych wydarzeń, jest dawanie świadectwa o tej tajemnicy paschalnej (por. Dz 2, 14-36) ${ }^{22}$. Wiara w zmartwychwstanie pozwala wierzącemu odnaleźć źródło zbawienia. Całe życie chrześcijańskie, oparte na wierze w paschalne dzieło zbawcze, powinno być odwzorowaniem tego misterium Chrystusa.

Z encykliki Lumen fidei wynika, że to głęboko chrystocentryczne i paschalne ujmowanie wiary dopełnione jest u św. Pawła eklezjalnym wymiarem wiary. Przede wszystkim wiara, o której mówi i do której wzywa św. Paweł, nie jest wiarą jedynie poszczególnego ochrzczonego, ale jest także postawą całej wspólnoty, a jednocześnie czymś, co wspólnotę Kościoła buduje. „W ten sposób - zuważa Franciszek - życie z wiary staje się życiem kościelnym”23.

Apostoł Paweł mówi także o wierze w kontekście usprawiedliwienia, co przeciwstawia się koncepcji judaistycznej wiążącej usprawiedliwienie $\mathrm{z}$ wypełnianiem Prawa (por. Rz 3, 20-22. 25. 28; 4, 2. 5-6; 9, 30-32; 10, 4-13; Ga 2, 16; 3, 6-29; Flp 3, 9) 24. „To właśnie - jak podkreśla Franciszek w Lumen fidei - stanowi kontekst polemiki św. Pawła z faryzeuszami, dyskusji na temat zbawienia przez wiarę albo przez uczynki prawa. Św. Paweł odrzuca postawę człowieka

${ }^{21}$ Por. LF 17-18. Por. także: Sobór Watykański II, Konstytucja dogmatyczna o Kościele Lumen gentium, nr 48, w: Sobór Watykański II, Konstytucje..., dz. cyt.

22 Por. LF 37.

${ }^{23}$ LF 22.

${ }^{24}$ Por. P. Łabuda, Wiara w nauce Apostoła Pawła..., dz. cyt., s. 132-143. 
pragnącego usprawiedliwić samego siebie przed Bogiem poprzez własne uczynki”25. Apostoł, mówiąc o wierze dającej usprawiedliwienie, miał na myśli pełne pojęcie wiary, które łączy w sobie i nadzieję, i miłość (por. Ga 5, 6). Chociaż nie oddziela wiary od miłości, to jednak mówi, że wiara pozbawiona miłości jest niczym: „Gdybym też miał [...] wszelką możliwą wiarę, tak iż bym góry przenosił, a miłości bym nie miał, byłbym niczym" (1 Kor 13, 2) ${ }^{26}$. W perspektywie życia moralnego najważniejsze jest tu podkreślenie, że wiara oznacza odrzucenie wszelkiej formy samozbawienia, czyli przypisywania zbawienia czysto ludzkim wysiłkom.

$\mathrm{Na}$ istotę wiary zwraca też uwagę św. Jan Apostoł. W jego pismach wiara jest przedstawiona bardzo wyraźnie jako dar Boga (por. J 6, 44, J 6, 56). Oczywiście ta nauka Jana nie oznacza, że nie widzi on wkładu człowieka i jego odpowiedzialności za wiarę. Stąd nie ma usprawiedliwienia dla tych, którzy widzieli czyny Jezusa, a nie wierzyli Mu (por. J 15, 22-25). Niewiara jest więc wielkim grzechem (por. J 16, 9).

Wiara, którą głosi św. Jan, jest nade wszystko wiarą w Chrystusa i wiarą w Chrystusie ${ }^{27}$. W Lumen fidei Franciszek pisze: „Oprócz «wierzyć», że prawdą jest to, co mówi Jezus (por. J 14, 10; 2, 31), Jan używa także wyrażeń: «wierzyć» Jezusowi oraz «wierzyć w» Jezusa"28. Trzeba zatem wedle tych słów wierzyć nie tylko Chrystusowi, ale i w Niego (por. np. J 6, 29. 35. 40; 7, 5. 38. 48; 8, 30; 9, 35). Papież Franciszek zauważa też, że apostoł Jan wiele mówi o poznaniu wiary, ukazuje również wzajemne implikacje wiary i miłości: „Wierzymy w Jezusa, gdy przyjmujemy Go osobiście w naszym życiu, przyłączając się do Niego w miłości oraz idąc za Nim na naszej drodze (por. J 2, 11; 6, 47; 12, 44)”29. Święty Jan wskazuje też na wiarę jako decyzję zbawczą człowieka. Kto wierzy w Chrystusa, posiada już życie wieczne. „Kto wierzy w Niego, nie podlega potępieniu, a kto nie wierzy, już został potępiony, bo nie uwierzył w imię Jednorodzonego Syna Bożego" (J 3, 18).

Ta więc biblijna doktryna na temat istoty wiary ostatecznie ukazuje, że dar wiary rodzi się w oparciu o Chrystusa i dlatego On jest w punkcie wyjścia i dojścia ludzkiej drogi ku Bogu. Należy zresztą pamiętać, że także całe stworzenie

25 LF 19.

26 Por. LF 51.

${ }_{27}$ Por. H. Sławiński, Oryginalne ujęcie kwestii wiary w encyklice papieża Franciszka „Lumen fidei”, „Polonia Sacra” 17 (2013), s. 99-100.

28 LF 18.

29 LF 18. 
i historia człowieka ma wymiar chrystocentryczny, bo wszystko ku Niemu ostatecznie prowadzi. Przecież wszystko stało się przez Chrystusa i wszystko zmierzało ku temu, by „Słowo stało się Ciałem i zamieszkało wśród nas” (J 1, 14).

\section{Wiara w kontekście samoudzielenia i samoobdarowania człowieka przez Boga w Chrystusie}

Nauczanie płynące z Biblii oraz przekazywane przez Magisterium Kościoła wskazuje, że zarówno w Starym i Nowym Przymierzu Bóg pragnie, aby wszyscy ludzie zostali zbawieni i doszli do poznania prawdy (por. $1 \mathrm{Tm} \mathrm{2,} \mathrm{4;} \mathrm{4,} \mathrm{10;}$ J 14, 6; 17, 3; 2 Kor 4, 2). To pragnienie odnosi się do wszystkich ludzi i całego świata. Boży zamysł zbawienia jest najwyraźniej widoczny w historii, której kulminacyjny punkt stanowi posłanie na świat Boga-Człowieka, Wcielone

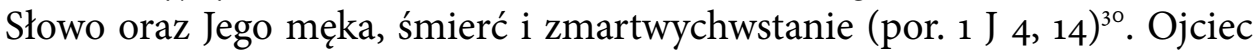
święty Franciszek wyraźnie potwierdza ten fakt w encyklice Lumen fidei: „Tylko tak, przez Wcielenie, przez udział w naszym człowieczeństwie, poznanie właściwe miłości mogło osiągnąć pełnię. Światło miłości rodzi się bowiem, kiedy zostaje poruszone nasze serce i przyjmujemy tym samym wewnętrzną obecność umiłowanego w nas, pozwalającą nam poznać Jego tajemnicę [...]. Przez swoje Wcielenie i przyjście do nas Jezus dotknął nas, i dotyka również dzisiaj [...]. W ten sposób, przemieniając nasze serce, pozwolił nam i nadal pozwala rozpoznawać Go i wyznawać jako Syna Bożego. Dzięki wierze także i my możemy Go dotknąć i otrzymać moc Jego łaski”’”.

Jezus Chrystus przyszedł na świat jako „posłany” przez Ojca. To posłanie (missio) ma swoje oparcie w odwiecznym pochodzeniu od Ojca. W ten sposób Ojciec objawia Syna światu, ale także Syn świadczy o Swoim Ojcu i objawia Go światu. Dzięki Jezusowi człowiek może poznać Boga, ponieważ „nikt nie zna Syna, tylko Ojciec, ani też Ojca nikt nie zna, tylko Syn i ten, komu Syn zechce objawić" (Mt 11, 27). To objawienie Boga dokonało się nie tylko w słowach Jezusa, lecz przede wszystkim w życiu Chrystusa na ziemi. Jako Syn Boży, który przyszedł na świat za sprawą Ducha Świętego, spełniał swoje mesjańskie posłannictwo w mocy Tego Ducha, również ta moc w sposób szczególny objawiła się w zbawczej ofierze i zmartwychwstaniu Chrystusa ${ }^{32}$.

3o Por. M. Pyc, Jezus Chrystus - centrum chrześcijańskiej wiary w świetle encykliki „Lumen fidei”, „Colloquia Theologica Ottoniana” 1 (2015), s. 215-228.

${ }^{31}$ LF 31.

${ }^{32}$ Por. J. Królikowski, Syn Boży i nasz Zbawiciel, Kraków 2014, s. 15-18. 
Samoudzielenie się Boga w ten sposób ukazuje głębię tajemnicy trynitarnej, którą odsłania Jezus Chrystus. Ewangeliczne przesłanie ukazuje więc prawdę o Ojcu, który posyła swojego Syna w mocy Ducha Świętego ${ }^{33}$.

Chrystus, ukazując swoim życiem Tego, który Go posłał, także pozwala odnaleźć odpowiedź na to, kim jest On sam. W Chrystusie i przez Chrystusa Bóg objawia się ludzkości najpełniej, najbardziej przybliża się do człowieka, a także równocześnie w Nim i przez Niego człowiek zdobył pełną świadomość swojej godności, swojego wyniesienia, nadprzyrodzonej wartości swojego człowieczeństwa, sensu swojego istnienia ${ }^{34}$. Chrystus swoim człowieczeństwem uświadamia, że posiada On przymioty boskie, podobnie jak Jego Ojciec. Wiele razy potwierdza swoją równość z Ojcem słowami: „Ojciec mój działa, aż do tej chwili i Ja działam” ( 5,17$)$, a przede wszystkim: „Ja i Ojciec jedno jesteśmy” $(\mathrm{J} 10,30)^{35}$.

Papież Franciszek także dotyka tego istotnego problemu odnoszącego się do rozumienia wiary, a mianowicie samoudzielenia i samoobdarowania człowieka przez Boga, które najpełniej wyraziło się we wcieleniu i ofierze krzyża. „Najwyższym dowodem wiarygodności miłości Chrystusa - pisze papież we wspomnianej encyklice Lumen fidei - jest Jego śmierć za człowieka. Jeśli oddanie życia za przyjaciół jest najwyższym dowodem miłości (por. J 15, 13), Jezus ofiarował swoje za wszystkich, również za tych, którzy byli nieprzyjaciółmi, by w ten sposób przemienić serce. Oto dlaczego ewangeliści godzinę Krzyża postrzegali jako szczytowy moment spojrzenia wiary: w tej godzinie jaśnieje blask wielkości i głębi Bożej miłości”36. W tej godzinie Jezus Chrystus - Syn Boga żywego uczynił zadość odwiecznej miłości swojego Ojca, które od początku wyrażało się w stworzeniu świata, w obdarowywaniu człowieka wszelkim bogactwem tego stworzenia, w uczynieniu go „niewiele mniejszym od istot niebieskich" (por. Ps 8,6). To zadośćuczynienie odwiecznej Miłości było konsekwencją odejścia człowieka od Boga - grzechu, który po wielokroć się rozrastał i łamał Przymierze zawarte przez Boga z człowiekiem (por. Rdz 3, 6nn). Odkupienie świata jest więc usprawiedliwieniem człowieka dokonanym w jednym ludzkim sercu: w sercu Syna Bożego, aby mogło stać się sprawiedliwością wielu ${ }^{37}$.

\footnotetext{
${ }_{33}$ Por. J. Misiurek, Wiara i sakramenty w życiu duchowym, Częstochowa 2013, s. 98-99.

34 Por. Jan Paweł II, Encyklika Redemptor hominis [dalej: RH], Wrocław 1986, nr 11.

35 Por. J. Misiurek, Wiara i sakramenty..., dz. cyt., s. 88.

${ }^{36}$ Por. LF 16.

37 Por. RH 9.
} 
Tajemnica odkupienia, która wynika z wielkiej miłości Boga do stworzenia, jest zatem inicjatywą Boga samego, w której Syn Boży ofiarowuje się za grzesznych ludzi, aby przyprowadzić ich do swojego Ojca. Poprzez samoudzielenie i samoobdarowanie Bóg Stwórca „objawia się jako Bóg odkupienia, jako Bóg, który jest wierny sobie samemu (por. 1 Tes 5, 24), wierny swej miłości do człowieka i do świata" ${ }^{8}$. Bóg wychodzi nieustannie z inicjatywą. Jest to konieczny aspekt Bożego działania względem wiary człowieka. Sam Jezus w mowie eucharystycznej podkreśla: „nikt nie może przyjść do Mnie, jeżeli Go nie pociągnie Ojciec, który Mnie posłał” (J 6, 44). Jest to także wskazanie na konieczność wiary, lecz aby uwierzyć, trzeba być pociągniętym przez Boga. Boża inicjatywa, to pociągnięcie jest darem, wewnętrznym poruszeniem, które może doprowadzić przez wiarę do Jezusa (por. Iz 54, 13). Arcybiskup Fisichella nazywa to poruszenie gratia facit fidem, czyli łaską przemieniającą serce, która jest początkiem wiary, a więc podkreśla to, że pierwszeństwo zawsze należy do Boga, a serce dotknięte przez Ducha pozwala w Jezusie rozpoznać Syna Bożego ${ }^{39}$.

Boże poruszenie wskazuje na objawienie, które według papieża Franciszka ma charakter dialogiczny. Na ten fakt wskazuje również nauczanie Kościoła podkreślające tę cechę w odniesieniu do wiary. Bóg objawia się człowiekowi i nawiązuje z nim miłosny dialog, który opiera się na wzajemnym obdarowaniu. Stwórca jest Tym, który nawiązuje dialog ze swoim stworzeniem. W sposób szczególny dotyczy to człowieka, z którym zawiera On przymierze ${ }^{40}$. Wielokrotne łamanie tego przymierza „zmusza” Boga do podjęcia zdecydowanych i ostatecznych działań, które urzeczywistnia przez swojego Syna. „Przymus”, który porusza Boga, wypływa z Jego głębi, z miłości, jaką obdarza On człowieka.

Misterium Chrystusa - misterium męki, śmierci i zmartwychwstania - jest najwyższym wyrazem Bożej miłości wobec grzesznej ludzkości. Bóg, który objawia się w swoim Synu, otwiera człowiekowi możliwość osiągnięcia wiecznej radości. Przez kontemplowanie śmierci umacnia się ludzka wiara, która otrzymuje olśniewające światło, „gdy jawi się ona jako wiara w Jego niewzruszoną miłość ku nam, zdolną wejść w śmierć, aby nas zbawić. Jest rzeczą możliwą wierzyć w tę miłość, która nie uchyla się od śmierci, aby pokazać, jak bardzo mnie kocha; jej bezgraniczność przezwycięża wszelkie podejrzenia

${ }^{8}$ RH 9.

39 Por. R. Fisichella, Komentarz do encykliki papieża Franciszka „Lumen fidei”, tłum. K. Stopa, w: Franciszek, Encyklika Lumen fidei..., dz. cyt., s. 14.

${ }^{40}$ Por. E. Sienkiewicz, Wiara w świetle absolutnej prawdy - refleksja na kanwie encykliki papieża Franciszka „Lumen fidei”, „Studia Gnesnesia” 28 (2014), s. 142. 
i pozwala nam w pełni zawierzyć się Chrystusowi” ${ }^{41}$. Moc Bożej miłości ukazanej w śmierci krzyżowej podkreśla Jego inicjatywę zbawczą. Miłość Boga (eros) do człowieka ,jest w pełni agape. Nie tylko dlatego, że zostaje dana zupełnie bezinteresownie, bez żadnej uprzedniej zasługi, ale także dlatego, że jest miłością przebaczającą"42.

Miłość Boga względem człowieka, który popadł w grzech, jawi się jako miłość miłosierna. Wielkość, niezwykłość tej miłości ukazuje papież Benedykt XVI w encyklice Deus caritas est: „Zwłaszcza Ozeasz ukazuje nam wymiar agape w miłości Boga do człowieka, który nieskończenie przewyższa aspekt darmowości. Izrael dopuścił się «cudzołóstwa», zerwał Przymierze; Bóg powinien był go osądzić i wyrzec się go. Ale w tym właśnie Bóg okazuje się Bogiem, a nie człowiekiem: «Jakże cię mogę porzucić, Efraimie, i jak opuścić ciebie, Izraelu? [...]. Moje serce na to się wzdryga i rozpalają się moje wnętrzności. Nie chcę, aby wybuchnął płomień mego gniewu, i Efraima już więcej nie zniszczę, albowiem Bogiem jestem, nie człowiekiem; pośrodku ciebie jestem Ja - Święty» (Oz 11, 8-9)" "43. Miłosierna miłość Boga, będąca najdoskonalszym „rodzajem miłości”, jest miłością przebaczającą i w każdym momencie gotową przebaczyć. Na jej wielkość i siłę wskazuje fakt, że „Zwraca Boga przeciw Niemu samemu, Jego miłość przeciw Jego sprawiedliwości”44. Z tej miłości wyłania się perspektywa śmierci na krzyżu Syna Bożego, w którym Bóg tak bardzo miłujący staje się człowiekiem i przyjmuje Jego śmierć, w której godzi sprawiedliwość z miłością ${ }^{45}$.

Papież Franciszek, analizując sytuację współczesną, zauważa jednak, że „nasza kultura straciła zdolność dostrzegania konkretnej obecności Boga, Jego działania w świecie. Uważamy, że Bóg znajduje się w zaświatach, na innym poziomie rzeczywistości, oddzielony od naszych konkretnych relacji. Gdyby jednak tak było, gdyby Bóg nie był zdolnym do działania w świecie, Jego miłość nie byłaby prawdziwie potężna, prawdziwie rzeczywista, a zatem nie byłaby nawet prawdziwą miłością, zdolną zapewnić to szczęście, które obiecuje. Wówczas byłoby całkowicie obojętne, czy się w Niego wierzy, czy nie wierzy. Natomiast chrześcijanie wyznają konkretną i potężną miłość Boga, który naprawdę działa w historii i decyduje o jej ostatecznym przeznaczeniu. Tę miłość

\footnotetext{
${ }^{41}$ LF 16.

${ }^{42}$ Benedykt XVI, Encyklika Deus caritas est [dalej: DCE], Kraków 2006, nr 10.

43 DCE 10.

44 DCE 10.

${ }^{45}$ Por. DCE 10.
} 
można spotkać, ona objawiła się w pełni w męce, śmierci i zmartwychwstaniu Chrystusa"46. W odniesieniu do tej miłości, która jest cały czas aktualna i działająca, ludzkość nie może przyjmować biernej postawy. Człowiek, który doświadcza swojej słabej kondycji, wobec ofiary krzyża czuje się wewnętrznie przynaglony do odpowiedzenia swoją miłością na ofiarowaną mu miłość.

Relacja między Bogiem a człowiekiem, jak zauważa papież Franciszek, powinna być wzajemną wymianą, w której Bóg zwierza się i powierza człowiekowi, a człowiek z kolei zawierza się Jemu. Stwórca wychodzi ku człowiekowi, stawiając pierwszy krok. Człowiek niejako jest „zmuszony” postawić swój, aby wykazać chęć trwania przy Nim. Ten przymus jednak jest wyrazem wolnej woli człowieka. Zasadniczym motywem, który skłania człowieka do tego kroku, jest wewnętrzne słowo samego Boga. Zawierzając Bogu, człowiek daje jedynie odpowiedź na Jego powołanie, na poznaną miłość i obdarowanie miłością.

Odpowiedź człowieka na ów wolny akt miłości Bożej, który wyraża się w łasce pociągającej, będącej jednocześnie wezwaniem, powołaniem, jest w pewien sposób przylgnięciem do Boga, co wyraźnie oddaje hebrajski termin dabhag, rozumiany jako „przylgnąć” lub „zawisnąć na szyi” (por. Pwt 30, 19-20; $\mathrm{Rdz} 2,24)^{47}$. Jest to termin podkreślający pełność i doskonałość oddania. Przylgnięcie powinno dotyczyć całego człowieka. Perspektywa personalistyczna, „całoosobowa” w podejściu do wiary sprawia, że w życiu danego człowieka wyklucza się obszary autonomiczne, do których Bóg nie ma wstępu. Wiara w życiu moralnym, pozostająca w ścisłej relacji z miłością, stanowi niejako „wspólny mianownik” dla wielorakich i wielopłaszczyznowych działań człowieka. Szczególnie jest to widoczne w kontekście odkrywania sensu i celu życia, kiedy to człowiek własne plany życiowe odczytuje w świetle Bożego powołania.

Ale to przylgnięcie do Boga można rozumieć również jako postawę przyjaźni. Przyjaźń względem Boga w życiu człowieka widnieje w postawie ufności, nadziei i posłuszeństwa. Ojciec święty Franciszek w swoim nauczaniu potwierdza, że wiara jest ufnym i pełnym nadziei otwarciem się na dokonane w Chrystusie zbawcze działanie Boga ${ }^{48}$. Ufna nadzieja, w której człowiek oddaje się w wierze, jest także owocem Ducha Świętego i stanowi integralny element żywej wiary. Rola Ducha Świętego jest więc bardzo ważna dla aktu wiary człowieka. Ten akt wiary dokonuje się zatem przez Chrystusa w Duchu Świętym ku Ojcu. Stąd też podmiotem odpowiedzi musi być człowiek, który daje tę odpowiedź

\footnotetext{
46 LF 17.

47 Por. A. F. Dziuba, Dynamika wiary..., dz. cyt., s. 122.

48 Por. LF 19, 20.
} 
przez wiarę w Duchu Świętym z Chrystusem Bogu Ojcu, i to cały człowiek biorący po uwagę swoją egzystencję, w której został przez Boga stworzony ${ }^{49}$.

Całożyciowa odpowiedź człowieka na Boże powołanie do wiary powinna ujawniać się na przestrzeni całego życia, we wszystkim, co przynoszą zmienne koleje losu i nowe sytuacje życiowe. Wybór Boga, dana odpowiedź, w perspektywie biblijnej jawi się jako wybór zbawczy. Jest to odczytanie sensu własnego życia nie w odniesieniu do dobrowolnie wybranych wartości moralnych, ale w odniesieniu do ostatecznego zbawienia, które wyraża prawda o życiu z Bogiem i w Bogu ${ }^{50}$. Papież Franciszek wyraźnie podkreśla w Lumen fidei, że wiara jest w ścisłej relacji z życiem człowieka. Ona prowadzi go do zaufania i zawierzenia Chrystusowi oraz pozwala mu żyć według Jego przykładu, a więc miłując ponad wszystko Boga i innych ludzi ${ }^{51}$. W takiej postawie przedstawia się zespolenie wiary z miłością, które można zrozumieć jako formę poznania właściwą wierze zdolnej oświetlić życie człowieka, ponieważ „wiara poznaje w miarę jak jest związana z miłością, bowiem miłość wnosi światło"52. Bez wiary nie byłoby miłości prawdziwie chrześcijańskiej, a bez miłości pełnego poznania Boga i braci. Franciszek uczy, że „światło wiary jest w stanie uwydatnić bogactwo ludzkich relacji, to, że mogą trwać, być wiarygodne, ubogacać wspólne życie"s3.

Tak więc wiara, która jest odpowiedzią na Boże wezwanie, wywołuje reperkusje w życiu zarówno wierzącego, jak i jego bliźnich. Wiara w pełnym jej rozumieniu, w odniesieniu do Boga i człowieka, musi zatem wyrażać się w konkretnych postawach człowieka. Warto więc przyjrzeć się tym postawom, na których powinna przejawiać się odpowiedź człowieka na łaskę wiary.

\section{Odpowiedź na dar wiary wyrażona w konkretnych postawach człowieka}

Wiara jako dar otrzymany od Boga domaga się odpowiedzi ze strony otrzymującego. Nie można jej bowiem sprowadzić do postawy przyjmującej. Dialogiczny charakter i osobisty wybór to coś więcej - to wejście w osobistą

49 Por. A. Drożdż, Wiara - nadzieja - miłość. Teologia moralna szczegółowa, Tarnów 1994, S. 22.

$5^{\circ}$ Por. J. Moskałyk, Wiara jako synteza stuchania $i$ widzenia według „Lumen fidei”, „Poznańskie Studia Teologiczne" 28 (2014), s. 159-161.

51 Por. LF 51, 55.

${ }^{52}$ LF 26.

53 LF 51. 
wspólnotę z Chrystusem. Taka wspólnota oznacza przede wszystkim głębokie przekształcenie człowieka i jego egzystencji. Wiara nie jest tylko aktem rozumowego przyjęcia prawd objawionych, chociaż ten element wchodzi w skład pojęcia wiary, ale to akt o znaczeniu integralnym, który polega na całkowitym przylgnięciu do Osoby Jezusa (por. Mt 11, 28-30), naśladowaniu Go (por. Mt 10, 38; Łk 14, 27), zaakceptowaniu Jego nauki i wcieleniu jej w życie (por. Mt 7, 24-27). Wiara otwiera więc nowe perspektywy doświadczenia zbawczego działania (por. Mk 5, 36; Łk 8, 50). To doświadczenie wywiera zbawienny wpływ na wiarę człowieka, a ma się ono wyrazić się w konkretnych przejawach ludzkiego życia.

Pierwszą autentyczną postawą, w której ma się wyrazić odpowiedź człowieka na dar wiary, jest pokora. Papież Franciszek w encyklice Lumen fidei uświadamia, że jeżeli wiara jest osobistym powołaniem danym człowiekowi, to na płaszczyźnie moralnej domaga się przede wszystkim postawy pokory: „Wierzący nie jest arogancki, przeciwnie, prawda daje mu pokorę, bo wie on, że nie my ją posiadamy, ale to ona nas bierze w posiadanie" 54 . Dzięki właściwie ukształtowanej pokorze człowiek zna wartość swojej osoby, stworzonej przez Boga ${ }^{55}$. Jest ona zatem „cnotą specyficznie chrześcijańską, i to jedną z najbardziej podstawowych, chociaż sama w sobie nie jest cnotą najwznioślejszą"56. Chrześcijańska pokora wzoruje się na Chrystusie, dlatego wraz z wiarą stanowi fundament chrześcijańskiego życia moralnego. Jezus Chrystus jawi się nie tylko jako nauczyciel, lecz przede wszystkim jako wzór pokory, o czym pisze św. Paweł w Liście do Filipian: „On to, istniejąc w postaci Bożej, nie skorzystał ze sposobności, aby na równi być z Bogiem, lecz ogołocił samego siebie, przyjąwszy postać sługi, stając się podobnym do ludzi” (Flp 2, 6-7).

Pokora w życiu Jezusa zaznacza się w całym Jego życiu - od wcielenia, przez ucieczkę do Egiptu, życie ukryte, poddanie się Maryi i Józefowi, przez wybór prostych współpracowników - apostołów, aż do ukazania jej w sposób najpełniejszy w męce i śmierci ${ }^{57}$. W tym ujawnia się odniesienie Syna względem Ojca, w których stawia On wolę Jego ponad swoją (por. Łk 22, 42). Trzeba zatem zawsze swoją pokorę widzieć w świetle pokory Boga.

54 LF 34 .

55 Por. S. Witek, Teologiczna interpretacja pokory, „Roczniki Teologiczno-Kanoniczne” 12 (1965) Z. 3, s. 8 .

${ }_{56}$ A. Słomkowski, Teologia życia duchowego w świetle Soboru Watykańskiego II, Ząbki 20oo, S. 158.

${ }_{57}$ Por. A. Słomkowski, Teologia życia duchowego..., dz. cyt., s. 160. 
Na wzór Chrystusa pokora powinna mieć dwojakie odniesienie: do Boga i do człowieka. Wymaga ona uznania tego, że człowiek jest bytem stworzonym. Wiara, która cechuje się pokorą, uświadamia człowiekowi jego całkowitą zależność od Boga. Ta zależność dotyczy zarówno tego, czym człowiek jest, jak i tego, co posiada i czyni. Święty Paweł podkreśla: „łaską bowiem jesteście zbawieni przez wiarę. A to pochodzi nie od was, lecz jest darem Boga, nie z uczynków, aby się nikt nie chlubił” (Ef 2, 8). Jeżeli zabraknie odniesienia do Boga lub zepchnie się Go na dalszy plan własnego życia, to istnieje niebezpieczeństwo popadnięcia w pychę ${ }^{58}$.

Znaczenie pokory dla wiary człowieka jest więc bardzo istotne. To właśnie ta cnota pozwala mu uznać swoją małość i usposobić go do oddania się swojemu ostatecznemu celowi. Nie można jednak patrzeć na nią w sposób pejoratywny, jak czynili to starożytni Grecy czy Rzymianie, ale należy się w niej dopatrywać wielkości człowieka z racji godności udzielonej przez Boga. Pokora jest odwagą pozwalającą żyć w prawdzie, na której opiera się cała struktura nadprzyrodzonej wielkości chrześcijańskiej ${ }^{59}$.

Pokora względem Boga prowadzi do pokory wobec bliźniego. Ona także wymaga od człowieka spojrzenia na siebie w prawdzie. Widzenie siebie w prawdzie należy rozumieć jako „widzenie siebie takim, jakim się jest i tak też należy widzieć bliźniego, a więc uznawać w bliźnim dary, którymi Bóg go obdarzył oraz widzieć też w sobie dary otrzymane od Boga. Ponieważ jednak patrzy się na nie jako na dary otrzymane od Boga i widzi się zgodnie z prawdą swe niedociągnięcia, upadki, niewierność i słabość, nie będzie powodu, by się nad kogokolwiek wywyższać”' . Pokora wobec bliźnich pozwala doskonalej wierzyć w Boży zamysł oraz przyjmować wobec Niego samego i wobec innych właściwą postawę.

Obok pokory człowiek powinien charakteryzować się - zdaniem papieża Franciszka - także wdzięcznością za łaskę wiary. Jest ona ściśle związana z pokorą, gdyż „światło, które niesie wiara, związane jest [...] z wdzięcznym wspomnieniem dobrodziejstw otrzymanych od Boga"61. Pokora pozwala człowiekowi uporządkować swój stosunek względem wszelkiego stworzenia oraz przyjąć odpowiednią postawę wobec daru otrzymanego od Stwórcy. Wdzięczność

${ }^{8}$ Por. R. Garrigou-Lagrange, Trzy okresy życia wewnętrznego, t. 1, tłum. T. Landy, Poznań 1960, s. 380-386.

59 Por. S. Witek, Teologiczna interpretacja pokory..., dz. cyt., s. 10.

${ }^{60}$ A. Słomkowski, Teologia życia duchowego..., dz. cyt., s. 161.

${ }^{61}$ LF 12. 
powinna objawiać się w życiu chrześcijanina jako stała dyspozycja duchowa, ponieważ ona ukazuje człowieka jako w pełni wierzącego, jako tego, który całkowicie powierzył siebie Bogu. Wiara powinna przejawiać się w postawie wdzięczności wobec Tego, który ze swego postanowienia ofiarowuje siebie w Synu, aby zbawić ludzkość. Dlatego św. Paweł pisze: „Lecz my zawsze winniśmy dziękować Bogu za was, bracia, umiłowani przez Pana, że wybrał was Bóg do zbawienia" (2 Tes 2, 13).

Wdzięczność za dar wiary ma jeszcze jeden istotny wymiar. To sam Jezus uczy człowieka właściwej postawy wdzięczności. W czasie swojego ziemskiego życia ukazywał, że ta postawa pozwala otworzyć się i oczekiwać jeszcze większych darów. Kiedy Jezus prosi swojego Ojca o wielkie dary, to rozpoczyna swoją prośbę od dziękczynienia (por. J 6, 11-13). Ale wiara, która wyraża się w dziękczynieniu, nie tylko otwiera człowieka na większe dary, lecz także pozwala mu dostrzec wielką wartość darów już otrzymanych.

Moralny aspekt wiary uwidacznia się również w postawie zaangażowania. Ojciec święty Franciszek bardzo mocno akcentuje tę płaszczyznę, wskazując, że wyznawanie wiary musi być połączone z zaangażowaniem całej osoby w życie chrześcijańskie ${ }^{62}$. Zaangażowanie w płaszczyźnie wiary wyraża się zarówno w znajomości prawd objawionych, jak i w praktykowaniu oraz ochronie wiary.

Wiara, która pozostaje w ścisłej relacji z rozumem, wymaga od wierzącego zaangażowania na płaszczyźnie intelektualnej. Człowiek wierzący ma za zadanie zgłębiać treść Objawienia. Wiara umożliwia wierzącemu udział w wiedzy, jaką Bóg ma o sobie samym. Im większe zaangażowanie rozumu w wierze, tym bardziej wzrasta jej wartość w życiu wierzącego. Ponieważ jednak wiara nie jest wyłącznie aktem rozumu, trzeba zwrócić uwagę na jej praktykowanie. Jakubowe wezwanie do pełnienia uczynków wiary w sposób szczególny wybrzmiewa w dzisiejszych czasach, w których wiara nie jest rozumiana integralnie, lecz w sposób wybiórczy, ograniczający się albo do racjonalistycznego, albo duchowego jej wymiaru. Kategoria zaangażowania wpisuje się w całożyciowy kontekst powołania chrześcijańskiego, dlatego powinna przejawiać się we wszelkich przejawach ludzkiego życia. Praktykowanie wiary - według papieża Franciszka - może dokonywać się w ludzkim życiu np. przez modlitwę, przyjmowanie sakramentów, życie według chrześcijańskich norm moralnych. Im większe jest zaangażowanie, tym wyższy będzie poziom życia moralnego. Życie chrześcijanina, który wyraża zaangażowanie w sferze swojej wiary, niejako jest także zobowiązaniem do obrony tejże cnoty.

62 Por. LF 41. 
Wiara, jeśli jest rzeczywistą odpowiedzią daną Bogu, powinna również wyrazić się w postawie nawrócenia. Ta postawa jest odpowiedzią na wezwanie Chrystusa, które kieruje On na początku Ewangelii według św. Marka: „Czas się wypełnił i bliskie jest królestwo Boże. Nawracajcie się i wierzcie w Ewangelię!” (Mk 1, 15). Papież Franciszek w encyklice Lumen fidei podkreśla, że odpowiedź dawana Bogu, przejawia się w postawie nawrócenia, w poświęceniu Mu całego życia ${ }^{63}$. Nawrócenie oznacza, że człowiek odrzuca dotychczasowy styl życia i obiera nową drogę życia. Jest to przede wszystkim zmiana dotychczasowego sposobu myślenia, odwrócenie się od grzechu i przyjęcie nowego sposobu życia - zgodnego z orędziem Ewangelii. Nawrócenie ma zatem fundamentalny charakter, ponieważ wiąże się z faktem, że chrześcijanin obdarzony łaską wiary i wezwany do nawrócenia, jest grzesznikiem, a sam grzech to akt nieposłuszeństwa wobec Boga, a więc zawsze pewien rodzaj aktu niewiary. W takiej perspektywie nawrócenie nie jest jednym $\mathrm{z}$ licznych elementów życia chrześcijańskiego, ale jest niejako principium wiary i całego życia człowieka. Nie można zatem nawrócenia rozpatrywać jako aktu jednorazowego. Prawdziwa wiara i postęp w wierze oznaczają nieustanne nawracanie się do Boga ${ }^{64}$.

Papież Benedykt zauważa, że „zasadnicze nawrócenie to niewątpliwie akt dokonany na zawsze. Jednak cierpliwa realizacja nawrócenia urzeczywistnia się podczas całego życia. Nie powinniśmy tracić ufności i trzymania się tej drogi. Musimy uznać, że nie możemy w jednej chwili stać się doskonałymi chrześcijanami. Warto jednak kroczyć naprzód, w wierności, by tak powiedzieć, wobec opcji podstawowej, a następnie trzymać się wytrwale drogi nawrócenia, co niekiedy staje się trudne"65. Chrześcijanie stają bowiem wobec trudnych wyborów w obliczu narzucanych „pseudowartości”, które są w opozycji do chrześcijańskiej moralności. Miarą współczesnego życia stają się dobra materialne, które przyjmują postać bożków. W kontekście tego niepokojącego zjawiska papież Franciszek w Lumen fidei stwierdza, że „wiara, ponieważ jest związana z nawróceniem, jest przeciwieństwem bałwochwalstwa; jest odsuwaniem się od bożków, by powrócić do Boga żywego, dzięki osobistemu spotkaniu. [...] Wiara polega na gotowości otwarcia się na wciąż nową przemianę

${ }^{63}$ Por. LF 13.

${ }^{64}$ Por. J. Nagórny, Wierzyć, ale jaki z tego pożytek, w: Czytając „Przekroczyć próg nadziei”, red. T. Styczeń, Z. J. Zdybicka, Lublin 1995, s. 184.

${ }_{65}$ Benedykt XVI, Nauczmy się wierzyć, tłum. W. Szymona, Kraków 2013, s. 46-47. 
dokonywaną przez Boże wezwanie" ${ }^{96}$. Oznacza to, że konieczne jest, aby Bóg znalazł się na powrót na szczycie hierarchii ludzkiego życia. To jest związane z koniecznością wsłuchiwania się w słowo Boga, aby uznać je za coś realnego i pozwolić mu oświecać życie. To pewnego rodzaju ryzyko podjęcia na nowo „eksperymentu z Bogiem”, w którym będzie On nieustannie przemieniał życie tego, kto do Niego się zwróci ${ }^{67}$. Nawrócony człowiek wraca do życia $w$ łasce Bożej. Życie duchowe nawróconego uzyskuje udział w tajemnicy śmierci i zmartwychwstania, która stanowi istotny element życia wiary. Jest to więc przejście od starego do nowego człowieka w Chrystusie. To przejście przynosi zmianę myśli i obyczajów ${ }^{68}$.

Zaakceptowanie nawrócenia prowadzi do naśladowania Chrystusa, które jest szczególną płaszczyzną wiary człowieka. Poprzez naśladowanie Chrystusa, życie Jego nauką chrześcijanin uzewnętrznia swoją wiarę. Pójście za Jezusem wymaga też w każdych warunkach dochowania Mu wierności. Wiąże się to z pogłębianiem wiary, aby coraz bardziej świadomie żyjąc według jej zasad, być wśród meandrów doczesności świadkiem Chrystusa. Papież Franciszek, mając szczególny wgląd w serce współczesnego człowieka, zachęca, aby nie bać się Chrystusa, lecz zaufać Mu i mieć odwagę pójść za Nim. Pójście za Jezusem jest przyzwoleniem na to, aby On był dla konkretnego człowieka Drogą, Prawdą i Życiem, czyli jego zbawieniem i szczęściem ${ }^{69}$.

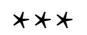

Z nauczania papieża Franciszka zawartego w encyklice Lumen fidei wynika, że zasadniczą perspektywę dla rozumienia wiary wyznacza prawda o Chrystusie - Synu Bożym, który stał się człowiekiem. Wiara jest zawsze odniesieniem do osoby Chrystusa i do Jego dzieła zbawienia. Dla chrześcijan Jezus Chrystus to nie tylko postać wpisująca się w historię ludzkości, lecz Objawiciel, który objawia człowieka samemu sobie, ukazuje mu sens jego życia, interpretuje go i przemienia. Jezus jest Tym, przez którego Bóg powołuje; jednocześnie Jego życie jest pierwszą i podstawową realizacją tego powołania na drodze

66 LF 13.

${ }_{77}$ Por. Benedykt xvi, Światłość świata. W rozmowie z Peterem Seewaldem, tłum. P. Napiwodzki, Kraków 2011, s. 74.

${ }^{68}$ Por. Sobór Watykański II, Dekret o działalności misyjnej Kościoła Ad gentes divinitus, nr 13, w: Sobór Watykański II, Konstytucje..., dz. cyt.

${ }^{69}$ Por. LF 14, 20, 21, 30. 
wiary ( stąd wezwanie do naśladowania), a On sam podstawowym warunkiem życia wiarą (konsekwentnie - także miłością). Taka wiara, będąca odkryciem źródła i celu życia człowieka, może być najpełniej odczytana w Chrystusie i przez Chrystusa. A zatem Objawienie i wiara, słowo i odpowiedź, miłość i jej odwzajemnienie tworzą łącznie jedną rzeczywistość historyczno-zbawczego objawienia, jedynego wydarzenia prawdy.

Wierzyć w Jezusa oznacza przyjąć Go całym sercem i umysłem, całą duszą i wszystkimi siłami, aby w ten sposób wejść na drogę budowania coraz doskonalszej miłości do Niego. To jest najbardziej specyficzny element wiary chrześcijańskiej. Oczywiście wiara, będąca przyjęciem Jego słowa, jest powierzeniem się Bogu, ale w sposób całkowicie wolny i osobowy. Szacunek dla godności i nienaruszalności osoby ludzkiej doprowadził Jezusa Chrystusa aż do śmierci. Każdy człowiek ma dla Niego imię, czyli jest kimś absolutnie jedynym, ponieważ został wybrany, przeznaczony i powołany przez Boga do życia będącego uczestnictwem w naturze Bożej. Współczesnemu człowiekowi pogrążonemu w beznadziejności wiara w Jezusa Chrystusa jawi się jako jedyna autentyczna odpowiedź - jedyny klucz do tego, co można nazwać metaforycznie ludzkim szyfrogramem, pod warunkiem, że zostają odkryte i są ukazywane niezgłębione bogactwa Jego tajemnicy i Jego daru ofiarowanego człowiekowi.

Według papieża Franciszka Jezus Chrystus jest podstawowym faktem chrześcijaństwa, co więcej, jest faktem będącym w stanie ciągłej nowości. Jezus Chrystus nie starzeje się w jednostajnie rozwijającej się historii świata, dzięki temu, że Jego „postać”, wyłaniająca się z Pisma Świętego i wiary Kościoła, nie zamyka się wobec spojrzenia wierzących w Niego - nie jest „wyizolowana” z naszej współczesności. Ten szczególny charakter postaci Jezusa Chrystusa sprawia, że wierzący wszystkich czasów wciąż doskonalej mogą wnikać w Jego nieskończoną głębię ontyczną, egzystencjalną i moralną.

\section{AbstrakT}

Zasadniczą perspektywę dla pojmowania wiary wyznacza prawda o Chrystusie Synu Bożym, który stał się człowiekiem. Wiara jest zawsze odniesieniem do osoby Chrystusa i do Jego dzieła zbawienia. Dla chrześcijan Jezus Chrystus jest Objawicielem, który objawia człowieka samemu sobie i ukazuje mu sens jego życia. Postać Jezusa Chrystusa sprawia, że wierzący wszystkich czasów mogą wciąż doskonalej wnikać w Jego nieskończoną głębię egzystencjalną i moralną.

Celem publikacji jest uświadomienie potrzeby wskazania konsekwencji, które wywołują w człowieku postać Chrystusa i Jego dzieło zbawienia. Chodzi zatem 
o odniesienie prowadzonej refleksji chrystologicznej do naszego życia, aby znaleźć odpowiedź na pytanie, kim jest Jezus Chrystus dla naszej wiary. Punktem odniesienia niniejszego studium jest encyklika Lumen fidei papieża Franciszka.

\section{SŁOWA KLUCZOWE}

Franciszek, Lumen fidei, wiara, Jezus Chrystus, człowiek, życie moralne

\section{Abstract}

\section{The Christo-Centrism of Faith in Lumen fidei by Pope Francis}

The fundamental outlook for the concept of faith is determined by the truth about Christ - the Son of God who became a man. Faith is always a reference to the person of Christ and to His work of salvation. For Christians, Jesus Christ is the Revealer who reveals man to himself and shows him he meaning of his life. The figure of Jesus Christ makes it possible for the believers of all times to continue examining His infinite existential and moral depth.

Therefore, the aim of this publication is to raise awareness of the need to indicate the consequences which induce the figure of Christ and His work of salvation in men. The point is the reference of the Christological reflection to our everyday life in attempt to answer the question of who Jesus Christ is to our faith. The following study is based on the encyclical Lumen fidei by the Pope Francis.

\section{KEYWORDS}

Francis, Lumen fidei, faith, Jesus Christ, man, moral life

\section{BIBLIOGRAFIA}

Bednarz M., Wiara w przekazie Ewangelii, w: Wierzę, red. P. Łabuda, Tarnów 2015, s. 71-118.

Benedykt XVI, Encyklika Deus caritas est, Kraków 2006.

Benedykt xvi, List apostolski Porta fidei, Kraków 2012.

Benedykt Xvi, Nauczmy się wierzyć, tłum. W. Szymona, Kraków 2013.

Benedykt XVI, Światłość świata. W rozmowie z Peterem Seewaldem, tłum. P. Napiwodzki, Kraków 2011.

Drożdż A., Wiara - nadzieja - miłość. Teologia moralna szczegółowa, Tarnów 1994.

Dziuba A. F., Dynamika wiary, Częstochowa 1997.

Fisichella R., Komentarz do encykliki papieża Franciszka „Lumen fidei”, tłum. K. Stopa, w: Franciszek, Encyklika Lumen fidei, Częstochowa 2013, s. 7-23. 
Garrigou-Lagrange R., Trzy okresy życia wewnętrznego, t. 1, tłum. T. Landy, Poznań 1960.

Głuchowski R., Zmaganie o czystość wiary w Jahwe, w: Wierzę, red. P. Łabuda, Tarnów 2015, s. 45-70.

Jan Paweł II, Encyklika Redemptor hominis, Wrocław 1986.

Katechizm Kościoła Katolickiego, Pallottinum, 1994.

Królikowski J., Syn Boży i nasz Zbawiciel, Kraków 2014.

Łabuda P., Wiara w nauce Apostoła Pawła, w: Wierzę, red. P. Łabuda, Tarnów 2015, s. $1119-157$.

Łanoszka M., Na drogach wiary biblijnego Izraela, w: Wierzę, red. P. Łabuda, Tarnów 2015, s. 15-44.

Misiurek J., Wiara i sakramenty w życiu duchowym, Częstochowa 2013.

Moskałyk J., Wiara jako synteza słuchania $i$ widzenia według „Lumen fidei”, „Poznańskie Studia Teologiczne" 28 (2014), s. 155-164.

Nagórny J., Fundamentalne zobowiązania moralne Izraela w ramach etyki Przymierza, „Roczniki Teologiczno-Kanoniczne” 27 (1980) z. 3, s. 5-20.

Nagórny J., Wierzyć, ale jaki z tego pożytek, w: Czytając „Przekroczyć próg nadziei”, red. T. Styczeń, Z. J. Zdybicka, Lublin 1995, s. 165-186.

Pyc M., Jezus Chrystus - centrum chrześcijańskiej wiary w świetle encykliki „Lumen fidei”, „Colloquia Theologica Ottoniana” 1 (2015), s. 215-228.

Sienkiewicz E., Wiara w świetle absolutnej prawdy - refleksja na kanwie encykliki papieża Franciszka „Lumen fidei”, „Studia Gnesnesia” 28 (2014), s. 137-149.

Sławiński H., Oryginalne ujęcie kwestii wiary w encyklice papieża Franciszka „Lumen fidei”, „Polonia Sacra” 17 (2013), s. 97-112.

Słomkowski A., Teologia życia duchowego w świetle Soboru Watykańskiego II, Ząbki 2000.

Sobór Watykański iI, Dekret o działalności misyjnej Kościoła Ad gentes divinitus, w: Sobór Watykański II, Konstytucje, dekrety, deklaracje, Poznań 2012, s. 433-471.

Sobór Watykański II, Konstytucja dogmatyczna o Kościele Lumen gentium, w: Sobór Watykański II, Konstytucje, dekrety, deklaracje, Poznań 2012, s. 104-166.

Sobór Watykański II, Konstytucja dogmatyczna o Objawieniu Bożym Dei Verbum, w: Sobór Watykański II, Konstytucje, dekrety, deklaracje, Poznań 2012, s. 350-363.

Sobór Watykański II, Konstytucja duszpasterska o Kościele w świecie współczesnym Gaudium et spes, w: Sobór Watykański II, Konstytucje, dekrety, deklaracje, Poznań 2012, s. 537-619.

Sobór Watykański II, Konstytucja o liturgii świętej Sacrosanctum concilium, w: Sobór Watykański II, Konstytucje, dekrety, deklaracje, Poznań 2012, s. 40-70. 
Witek S., Teologiczna interpretacja pokory, „Roczniki Teologiczno-Kanoniczne” 12 (1965) z. 3, s. 5-18.

Zawada S., Wiara, w: Jan Paweł II, Encyklopedia nauczania moralnego, red. J. Nagórny, K. Jeżyna, Radom 2005, s. 568-573. 